\title{
NUMBER AND ACTIVITY OF MICROORGANISMS IN SOIL INOCULATED WITH THE RHIZOCELL C BIOPREPARATION IN STRAWBERRY CULTIVATION (FRAGARIA × ANANASA DUCH.)
}

\author{
Małgorzata Hawrot-Paw'1, Grzegorz Mikiciuk², Małgorzata Mikiciuk³, \\ Monika Izwikow', Joanna Kiniorska' \\ 1 Department of Agrotechnical Systems Engineering, West Pomeranian University of Szczecin, Papieża Pawła \\ VI 1,71-459 Szczecin, Poland, e-mail: malgorzata.hawrot-paw@zut.edu.pl \\ 2 Department of Horticulture, West Pomeranian University of Szczecin, Słowackiego 17, 71-434 Szczecin, \\ Poland \\ 3 Department of Plant Physiology and Biochemistry, West Pomeranian University of Szczecin, Słowackiego 17, \\ 71-434 Szczecin, Poland
}

Received: 2015.12.10

Accepted: 2016.03.04

Published: 2016.04.01

\begin{abstract}
An experiment involving vegetation pots was conducted to assess the effect of inoculating the soil with the Rhizocell C biopreparation, which includes bacteria from the genus Bacillus amyloliquefaciens IT45, on the number and activity of selected groups of soil microorganisms. The biopreparation was applied in strawberries (Fragaria $\times$ ananasa Duch.) in a dose recommended by the manufacturer. Microbiological analyses were conducted four times during the vegetation of plants. The obtained results led to a conclusion that the use of biopreparation affects biological activity of soil, and a majority of the observed changes were beneficial. The mean number of the most microorganisms after Rhizocell C biopreparation was higher than in the control object. Soil inoculation had an influence on the activity of microorganisms determined based on biomass content, but the differences were not significant.
\end{abstract}

Keywords: biopreparation, microorganisms, biological activity, soil, Rhizocell C.

\section{INTRODUCTION}

Microorganisms are an integral part of soil and take part in the cycle of matter [Watanabe 2002, Winding et al. 2005], thus also affecting soil fertility, which determines achieving an appropriate quality and quantity of the harvest. Intense farming and industrial pollution contribute to soil degradation, including biological soil, and a stable qualitative and quantitative composition of soil microbiocenoses is important for a correct functioning of this environment [Schimel and Gulledge 1998, Cavigelli and Robertson 2000]. Microbiological preparations have been available on the market for a number of years; their goal is to promote the growth of plants [Vessey 2003, Martyniuk 2011], e.g. by stimulating biological activity of soil. These products contain special- ly selected cultures of bacteria or nutritive substances that benefit the development of soil microorganisms. Inoculating the soil may also assist the production processes of nutritive substances for plants [Barea et al. 2002]. A large group of preparations of this type is classified as biopesticides [Martyniuk 2012], which, according to their manufacturers, eliminate the causes of plant diseases and pests. These solutions may to some extent constitute an alternative for genetic modifications conducted on plants, which is why their use is considered safer. Strains that fix atmospheric nitrogen, referred to as free-living and symbiotic assimilators of nitrogen, are used successfully [Jarecki and Bobrecka-Jamro 2012].

The introduction of new biopreparations requires control research in order to, first and foremost, determine the need to use a preparation and 
to assess its effectiveness in relation to plants and the environment. The aim of this study was to analyse changes in the number of microorganisms belonging to selected groups microorganisms (total number of bacteria, amylolytic microorganisms, cellulolytic microorganisms, lipolytic microorganisms, proteolytic microorganisms, bacteria from the genus Azotobacter and Bacillus, actinobacteria, fungi and their activity following the inoculation of the soil using an Rhizocell $\mathrm{C}$ preparation containing active Bacillus amyloliquefaciens.

\section{MATERIALS AND METHODS}

The study on the effect of the Rhizocell C biopreparation on soil microorganisms was conducted as part of an experiment involving vegetation pots at the vegetation hall of West Pomeranian University of Technology in Szczecin, Poland. The biopreparation was used to inoculate soil in a cv. 'Rumba' strawberries.

The Rhizocell C is a yellowish powder, easily soluble in water that creates a suspension. The biopreparation contains Bacillus amyloliquefaciens IT45, which bind to the soil, primarily in the rhizosphere. These bacteria stimulate the growth of plant roots by exuding phytase, an enzyme affecting the transformations of phosphorus in the soil. The product also has a probiotic effect: it limits the growth of potentially pathogenic microorganisms [agriculture-de-conservation.com]. Before the inoculation, the product was mixed with a small amount of water at room temperature and left for an hour, after which water was added until the desired volume was reached $(1 \mathrm{~kg}$ of the preparation per $100 \mathrm{dm}^{3}$ of water). $100 \mathrm{~cm}^{3}$ of the suspension was used to water one plant, which corresponds to a dose of $1 \mathrm{~g}$ of the preparation per plant (a Kick pot with a volume of $10 \mathrm{dm}^{3}$, with $8 \mathrm{dm}^{3}$ of medium).

The assessment was conducted in two variants: the control (object C) and the experimental, in which the Rhizocell $\mathrm{C}$ was introduced into the soil (object Rh). Five pots were prepared for each variant of the assessment. Analyses were conducted four times during the vegetation of the plants, i.e. before inoculating the soil with the biopreparation (I), two weeks after the RC biopreparation was used (II), during the blooming (III), and during the fruition of the strawberries (IV).

The microbiological analyses, involved evaluating changes in the number of selected microorganisms, were determined by plating dilutions of soil using media suitable for different groups of microorganisms - bacteria on Bunt and Rovira's medium [1955], fungi on Martin's medium [1950], actinobacteria on Küster's medium [1971], amylolytic microorganisms on Cooney and Emerson's medium [1964], proteolytic microorganisms on Kędzia and Konar's medium [1974], cellulolytic microorganisms on Maliszewska's medium [1954], lipolytic microorganisms on Burbianka and Pliszka medium [1977], bacteria from the genus Azotobacter on Fenglerowa's medium [1965], bacteria from the genus Bacillus on medium $\left(\mathrm{g} \cdot \mathrm{dm}^{-3}\right)$ : yeast extract 5 , tryptone 10 , $\mathrm{NaCl} 10$, agar 15 , dist. $\mathrm{H}_{2} \mathrm{O} 1000$. The plates were incubated in a thermostat at $25^{\circ} \mathrm{C}$ : bacteria, lipolytic microorganisms, amylolytic microorganisms, proteolytic microorganisms, and bacteria from the genus Bacillus were incubated for three days, fungi and bacteria from the genus Azotobacter for 5 days, and actinobacteria and cellulolytic microorganisms for 7 days. The number of microorganism was given as CFUs in $1 \mathrm{~g}$ of dry soil matter. All measurements were conducted three times.

In addition to the number, the activity of microflora was determined based on the measured biomass content of living organisms using the SIR method [Anderson and Domsch 1978].

Statistical calculations were carried out using Statistica 12.0 program (StatSoft, Poland).

\section{RESULTS AND DISCUSION}

Assessing the direct effect of the use of soil biopreparations is a difficult task, primarily due to the existence of complicated, complex reactions between soil microorganisms [Martyniuk 2012].

The dynamics of changes in the number and activity of microorganisms is presented in Figure 1 , and mean number values from the entire duration of incubation are presented in Figure 2. The number of bacteria in the inoculated object $(\mathrm{Rh})$ in the presented research was usually higher than or equal to the values obtained for the control object $(135 \%$ of control values during strawberry fruition towards the end of the research). Kaczmarek et al. [2008] used a biopreparation containing effective microorganisms, and obtained over $150 \%$ more bacteria compared to the control sample. Derkowska et al. [2015] assessed the effect of biopreparations used in strawberry plantations 

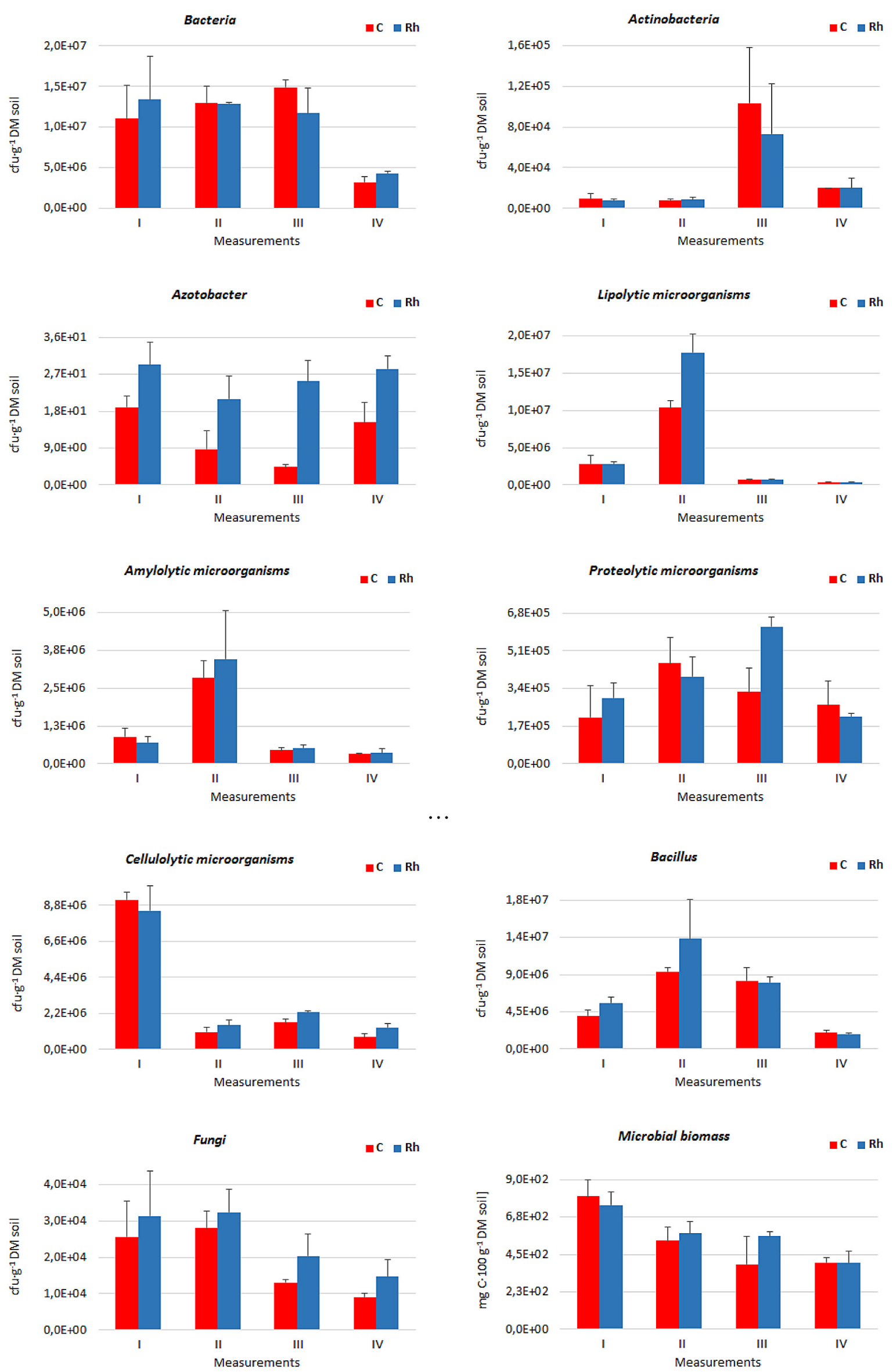

Figure 1. Dynamics of changes in the number and activity of microorganisms $(\mathrm{C}$ - control, $\mathrm{Rh}$ - soil + Rhizocell C) 


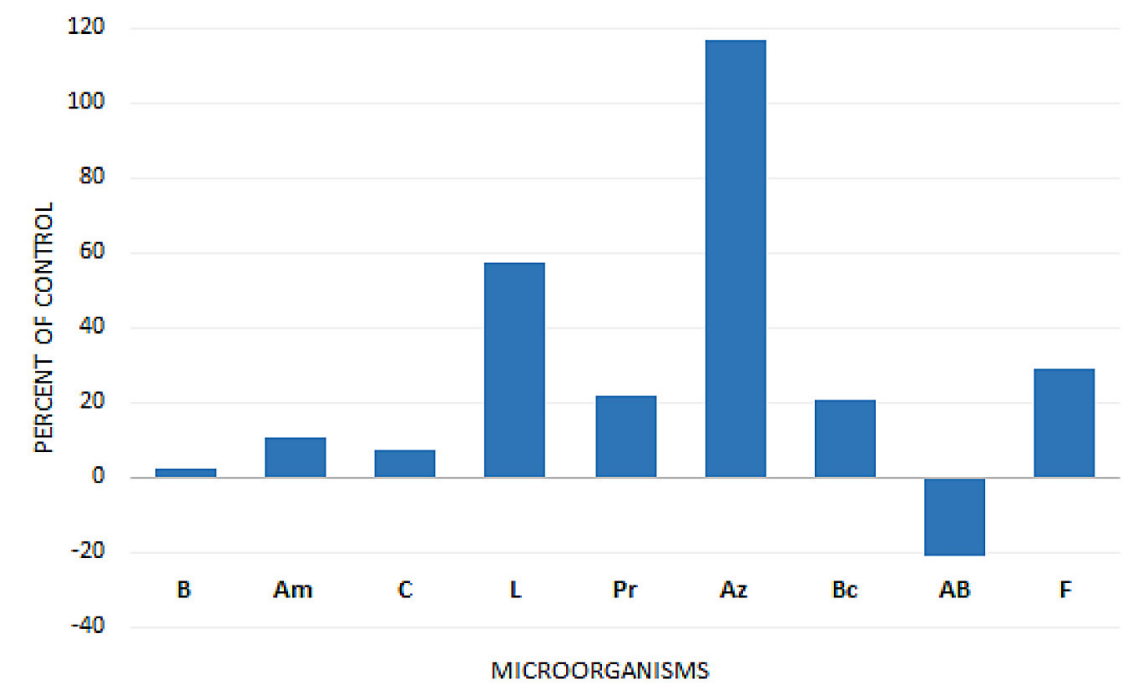

$\mathrm{B}$ - total number of bacteria, Am - amylolytic microorganisms, C - cellulolytic microorganisms, L - lipolytic microorganisms, $\mathrm{Pr}$ - proteolytic microorganisms, Az - Azotobacter, $\mathrm{Bc}$ - Bacillus, $\mathrm{AB}$ - actinobacteria, $\mathrm{F}$ - fungi

Figure 2. Mean number of microorganisms as a percentage of the control

not only on plant parameters, but on the number of bacteria and fungi as well. The assessment was conducted for two varieties of strawberry. A beneficial effect for microorganisms was noted only for one of the varieties following the inoculation of the soil using the Micosat F preparation (a complex of arbuscular fungi and rhizosphere bacteria).

The number of amylolytic microorganisms exceeded that in the control already two weeks after the soil was inoculated. However, these changes were statistically insignificant, unlike the lipolytic organisms. In an experiment assessing the effect of Azotobacterin on microorganisms, Wyszkowska et al. [2008], observed an increase in the number of cellulolytic microorganisms by 16\%. Wierzba and Nabrdalik [2005], after using a biopreparation containing e.g. Bacillus subtilis, Bacillus macerans, Pseudomonas fluorescens, Pseudomonas fragi, Serratia liquefaciens, Acinetobacter junii, Acinetobacter lvoffii, Cytophaga $s p$., observed a dynamic growth of these microorganisms that ranged from $1.5 \cdot 10^{5} \mathrm{cfu}$ to $1.5 \cdot 10^{7}$ $\mathrm{cfu} \cdot \mathrm{g}^{-1}$ of soil dry matter.

The number of bacteria from the genus $A z O-$ tobacter following the inoculation of the soil with the Rhizocell $\mathrm{C}$ biopreparation was significantly higher throughout the entire experiment than in control object. High values were also observed for bacteria from the genus Bacillus, which was likely due to the fact that a large number of them had been introduced into the inoculant. The same observation was made by other authors [Wyszkowska et al. 2008, Wyszkowska et al. 2013].
In a study by Kowalska et al. [2012], on the use of inoculants with effective microorganisms (EM), the number of actinobacteria in the studied sample decreased by nearly $70 \%$ compared to the control. A similar reduction, primarily during the III stage of measurement (strawberry blooming), was also noted in the presented study. The reduction in the number of actinobacteria, which are characterized by a high enzymatic activity [Breza-Boruta 2002, Anerek et al. 2006], could limit the rate of mineralisation of soil organic matter; however, the observed changes were statistically insignificant.

The number of fungi in the Rh object was higher than in the control object throughout the experiment. In studies by other authors, inoculating the soil with a preparation containing EM increased the number of fungi by over $30 \%$ after a longer period of incubation [Wielgosz et al. 2010 ] and by over $100 \%$ after multiple applications [Kowalska et al. 2012] compared to the control object. Some authors indicate the noticeable reduction in the number of fungi during plant blooming as primarily a result of changes in the composition and the amount of substances exuded by the plants [Wolna-Maruwka et al. 2010, Wolna-Maruwka et al. 2012].

Inoculating the soil promoted the activity of microorganisms. Throughout most of the experiment, the content of live organism biomass was higher by $10-45 \%$ compared to the control object, however, the differences were statistically insignificant.

The Rhizocell C biopreparation modified the state of microbiological equilibrium in the soil 


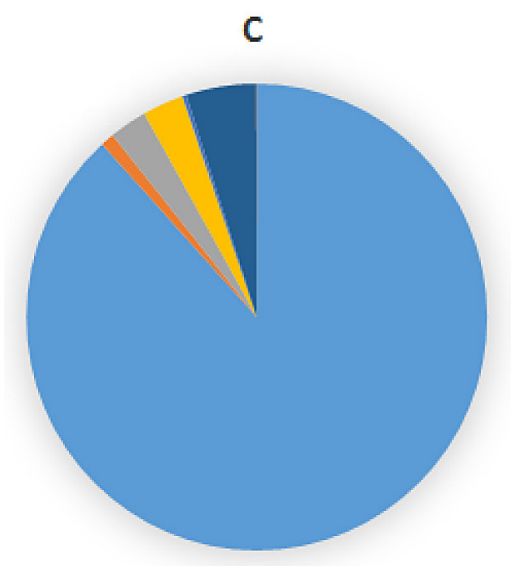

$\begin{array}{ll} & \\ \square \mathrm{B} & 88,28 \% \\ \square \mathrm{Am} & 0,95 \% \\ \square \mathrm{C} & 2,65 \% \\ \square \mathrm{L} & 2,90 \% \\ \square \mathrm{Pr} & 0,26 \% \\ \square \mathrm{Az} & 0,00 \% \\ \square \mathrm{BC} & 4,92 \% \\ \square \mathrm{AB} & 0,03 \% \\ \square \mathrm{F} & 0,02 \%\end{array}$

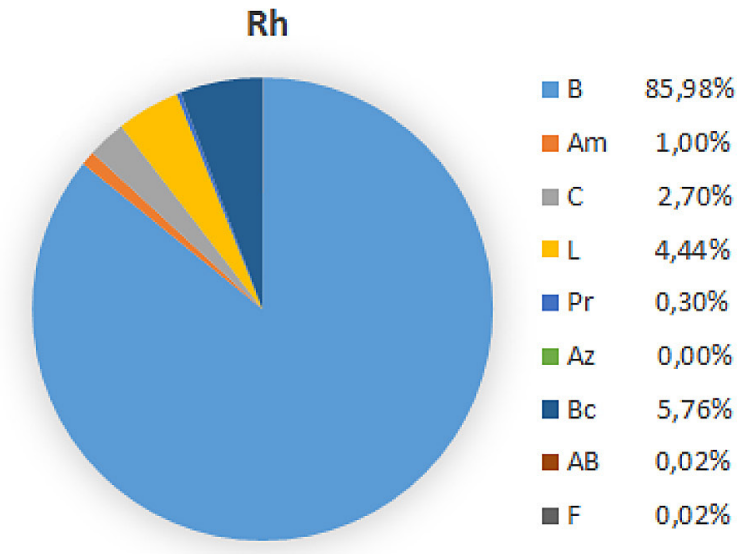

$\mathrm{B}$ - total number of bacteria, Am - amylolytic microorganisms, C - cellulolytic microorganisms, L - lipolytic microorganisms, $\mathrm{Pr}$ - proteolytic microorganisms, Az - Azotobacter, Bc - Bacillus, AB - actinobacteria, F - fungi

Figure 3. Percentage share of each group of microorganisms compared to the total number in the control object (C) and the object inoculated with the Rhizocell C preparation (Rh)

(Fiigure 3), however, the observed changes were only temporary. It should be noted that the main aim of the product is to stimulate the growth of plants, and the increase in the number of microorganisms belonging to most of the studied groups could have constituted an additional promoting factor for the plants.

Future studies are planned aimed at determining the limiting effect of the biopreparation on the growth of microorganisms, potentially pathogenic for plants, i.e., studies aimed at determining the potential probiotic properties of the inoculant.

\section{CONCLUSIONS}

The introduction of the Rhizocell C biopreparation into the soil affected the number and activity of microorganisms. The observed post-inoculation changes in the number of microorganisms may have been caused by a competition between the autochthonous microorganisms and those introduced with the inoculant. Some microorganisms returned to the state of microbiological equilibrium towards the end of the experiment, showing values close to control values. Taking into account mean number values from the entire experiment, from among the nine studied groups of microorganisms, only the actinobacteria showed a reduction comparable to the non-inoculated object.

\section{REFERENCES}

1. Anderson J.P.E., Domsch K.H. 1978. A physiological method for the quantitative measurement of microbial biomass in soils. Soil. Biol. Biochem., 10, 215.

2. Anerek B., Górska E.B., Russel S. 2006. Charakterystyka celulolitycznego szczepu Micromonospora rubra wyizolowanego z gleby. Acta Agr. Silv., Agraria, 49, 5-11.

3. Barea J.M., Azcon R., Azcon-Aguilar C. 2002. Mycorrhizosphere interactions to improve plant fitness and soil quality. Antonie Van Leeuwenhoek., 81(1-4), 343-351.

4. Breza-Boruta B. 2002. Wybrane właściwości enzymatyczne promieniowców z rodzaju Streptomyces wyizolowanych spod uprawy ziemniaka. Acta Sci. Pol., Agricultura, 1(1), 27-36.

5. Bunt J.S., Rovira A.D. 1955. Microbiological studies of some subantarctic soil. J. Soil Sci., 6 (1), 119-128.

6. Burbianka M., Pliszka A. 1977. Mikrobiologia żywności. PZWL, Warszawa.

7. Cavigelli M.A., Robertson G.P. 2000. The functional significance of denitrifier community composition in a terrestrial ecosystem. Ecology, 81, 1404-1414.

8. Cooney D.G., Emerson R. 1964. Termofilic fungi. Freeman, London.

9. Derkowska E., Sas Paszt L., Harbuzov A., Sumorok B. 2015. Rooth growth, mycorrhizal frequency and soil microorganisms in strawberry as affected by biopreparations. Adv. Microbiol., 5, 65-73.

10. Fenglerowa W. 1965. Simple method for counting Azotobacter in soil samples. Acta Microbiol. Pol., 14, 203.

11. Jarecki W., Bobrecka-Jamro D. 2012. Reaction of white lupine (Lupinus albus L.) to seed inoculation with nitragina. Acta. Sci. Pol, Agricultura, 11(2), 19-26. 
12. Kaczmarek Z., Wolna-Maruwka A., Jakubus M. 2008. Zmiany liczebności wybranych grup drobnoustrojów glebowych oraz aktywności enzymatycznej w glebie inokulowanej Efektywnymi Mikroorganizmami (EM). J. Res. Appl. Agric. Eng., 53(3), 122-127. [in Polish.]

13. Kędzia W., Konar H. 1974. Diagnostyka mikrobiologiczna. PZWL, Warszawa

14. Kowalska J., Sosnowska D., Remlein-Starosta D., Drożdżyński D., Wojciechowska R., Łopatka L. 2012. Efektywne Mikroorganizmy w rolnictwie ekologicznym. Ministerstwo rolnictwa i rozwoju wsi, Warszawa, Falenty.

15. Küster E. 1971. Biologia gleby. PWRiL, Warszawa.

16. Maliszewska W. 1954. Proponowana szczegółowa metodyka analiz mikrobiologicznych gleby. IUNG, Puławy.

17. Martin J.P. 1950. Use of acid rose bengales and streptomycin in the plate method for estimating soil fungi. Soil Sci., 69, 215-233.

18. Martyniuk S. 2011. Skuteczne i nieskuteczne preparaty mikrobiologiczne stosowane $\mathrm{w}$ ochronie $\mathrm{i}$ uprawie roślin oraz rzetelne i nierzetelne metody ich oceny. Post. Mikrobiol., 50(4), 321-328.

19. Martyniuk S. 2012. Czy rozwój integrowanej ochrony roślin I rolnictwa ekologicznego zwiększy wykorzystanie biopestycydów w praktyce rolniczej? J. Res. Appl. Agric. Eng., 57(4), 35-37.

20. Schimel J.P., Gulledge J. 1998. Microbial community structure and global trace gases. Global Change Biol., 4, 745-758.

21. Vessey J.K. 2003. Plant growth promoting Rhizobacteria as biofertilizers. Plant and Soil, 255, 571-586.

22. Watanabe K. 2002. Linking genetics, physiology and ecology: an interdisciplinary approach for ad- vancing bioremediation. J. Biosci. Bioeng., 94 (6), 557-565.

23. Wielgosz E., Dziamba S., Dziamba J. 2010. Effect of application of EM spraying on the populations and activity of soil microorganisms occurring in the root zone of spring barley. Pol. J. Soil Sci., 43, $65-72$.

24. Wierzba S., Nabrdalik M. 2005. Biocomposite for organic waste degradation. Physicochem. Probl. Miner. Process., 39, 249-256.

25. Winding A., Hund-Rinke K., Rutgers M. 2005. The use of microorganisms in ecological soil classification and assessment concept. Ecotoxicol. Environ. Saf., 62, 230-248.

26. Wolna-Maruwka A., Schroeter-Zakrzewska A., Borowiak K. 2010. Wpływ preparatu EM na stan mikrobiologiczny podłoża przeznaczonego do uprawy pelargonii (Pelargonium $\times$ hortorum). Nauka Przyr. Technol., 4(6), \#98.

27. Wolna-Maruwka A., Schroeter-Zakrzewska A., Borowiak K., Niewiadomska A. 2012. Impact of microbiological inoculum on numbers and activity f microorganisms in peat substrate and on growth and flowering of Scarlet sage. Pol. J. Environ. Stud., 21(6), 1881-1891.

28. Wyszkowska J., Kucharski J., Borowik A. 2013. Biological effects of L-tryptophan and the vaccine Azotobakteryna in soil. J. Res. Appl. Agric. Eng., 58(4), 238-241.

29. Wyszkowska J., Kucharski M., Kucharski J. 2008. Microbiological and biochemical properties of soil depending on adenine and Azotobacterin applied. J. Elem., 13, 127-137.

30. http://agriculture-de-conservation.com/sites/agriculture-de-conservation.com/IMG/pdf/gamme-lallemand.pdf, dostęp z dnia 22.06.2015. 